M.S. Demydov, Ya.A. Shapovalov, D.0. Astafiev, Yu.I. Demchenko

\title{
ABOUT REGULARITIES OF TECHNOLOGICAL PARAMETERS INFLUENCE ON ACCIDENT-FREE MINING OF FLAT COAL SEAMS BY PLOW SYSTEMS
}

Analysis of research and publication on concerned topic is given. Analysis of stratigraphic columns of investigated seam is executed. Distance influence from wall face on loading character of mechanized support sections is determined. Regularities of loading changing on support sections at different advance rate of stoping face are substantiated.

ПРО ЗАКОНОМІРНОСТІ ВПЛИВУ ТЕХНОЛОГІЧНИХ ПАРАМЕТРІВ НА БЕЗАВАРІЙНЕ ВІДПРАЦЮВАННЯ ПОЛОГИХ ВУГІЛЬНИХ ПЛАСТІВ СТРУГОВИМИ КОМПЛЕКСАМИ

Наведено аналіз досліджень і публікацій за даною тематикою. Виконано аналіз стратиграфічних колонок досліджуваного пласта. Визначено вплив відстані від груді вибою на характер навантаження секцій механізованого кріплення. Обгрунтовано закономірності зміни навантаження на секції кріплення при різних швидкостях посування вибою.

\section{О ЗАКОНОМЕРНОСТЯХ ВЛИЯНИЯ ТЕХНОЛОГИЧЕСКИХ ПАРАМЕТРОВ НА БЕЗАВАРИЙНУЮ ОТРАБОТКУ ПОЛОГИХ УГОЛЬНЫХ ПЛАСТОВ СТРУГОВЫМИ КОМПЛЕКСАМИ}

Приведен анализ исследований и публикаций по данной тематике. Выполнен анализ стратиграфических колонок исследуемого пласта. Определено влияние расстояния от груди забоя на характер нагружения секций механизированной крепи. Обоснованы закономерности изменения нагрузки на секции крепи при различных скоростях подвигания забоя.

ISSUE AND ITS CONNECTION WITH SCIENTIFIC AND PRACTICAL TASKS

Realization of accident-free operation of stoping face in modern conditions is actual, but at same times enough difficult task. In Western Donbass conditions question about appliance of new high-productive equipment demands analysis of mine-geological, mine-technical and productive factors for whole potential re- alization.

In consequence of complex impact of above mentioned factors decrease productivity of stoping equipment and operations safety.

With the application of new highproductive plow systems with daily average advance rate $V=5-12 \mathrm{~m} /$ day in conditions of slightly metamorphized foliated massif was observed cases of mechanized support transformation to "rigid base". Previously in same 
conditions, but at less advance rate this fact hadn't been observed.

\section{FORMULATING THE PROBLEM}

During seam mining in slightly metamorphized rock massif at different values of mine-geological, mine-technical and productive factors change character of mechanized support sections loading.

Hence the problem of prediction of given factors interrelation and their influence on steady work of mechanized system has great scientific and practical importance.

\section{ANALYSIS OF RESEARCH AND PUBLICATION}

Parameters of rock movement area during stoping mining in scientific works of prof. A. Savostianov [1] had been substantiated by analytical research of mine massif model that has joint-block interrelations between elements.

Solution of this problem had been realized by collective under command of prof. I. Kiyashko (A. Koshka, N. Ovchinnikov, V. Kharchenko, etc.) who considered both parameters of above-the-coal strata movement during mining of very thin coal seams [2] and interrelation of mechanized systems with side rocks. In scientific work [3] of V. Sulaev was substantiated mechanism of stratification and failure of above-the-coal strata in process of stoping operations conduction.

Because of computer technology development and increasing of its processing speed in recent years appears possibility to simulate rock massif condition during stoping extraction with using of finite elements method (FEM). Collective under command of prof. V. Bondarenko (G. Symanovych, I. Kovalevska, $\mathrm{V}$. Fomychov, etc.) is engaged in this direction [4].

Although great volume of work in this area is done, but questions about interrelation and influence of main mine-geological, minetechnical and productive factors on mecha- nized support steadiness of plow face are considered insufficiently full.

\section{MATERIAL STATEMENT AND RESULTS}

The main initial data for assigned tasks solution are quantity indices of following minegeological and mine-technical parameters:

- stopping time of stoping face $-t_{\text {stop }}$;

- advance rate of stoping face $-V_{f}$;

- structure of main roof (on investigated unit);

- distance from sections to wall face $-\Delta_{f}$; length.

- section location along the longwall

These parameters were received by pressure monitoring of mechanized support sections during mining of longwall $161^{\text {st }}$ seam $C_{6}$ "Stepnaya" mine "Pershotravenskoe" Mine Management PJSC "DTEK Pavlogradugol". During the period of monitoring two times was observed mechanized plow system transformation to "rigid base" that led to outage and longtime repair measures on support sections conditioning.

Greatest challenge for getting consistent results was unit's selection with similar structure of main roof (fig. 1).

Selection criteria of investigated units:

- absence of thick sandstone layers or other rocks in roof that have increased hardness;

- similar structural composition of roof (thickness of lithological differences on two investigated units should not differs on more than $10-15 \%$ );

- strength and deformational characteristics of analyzed lithological differences should not differs on more than $10-15 \%$.

Analyzing above represented stratigraphic columns on fig. 1 along the seam $C_{6}$ we determining that for further statistical processing meet the requirements units $\# 1$ and 2 that have similar structure of main roof. That is why in further research we will apply them as basic. 


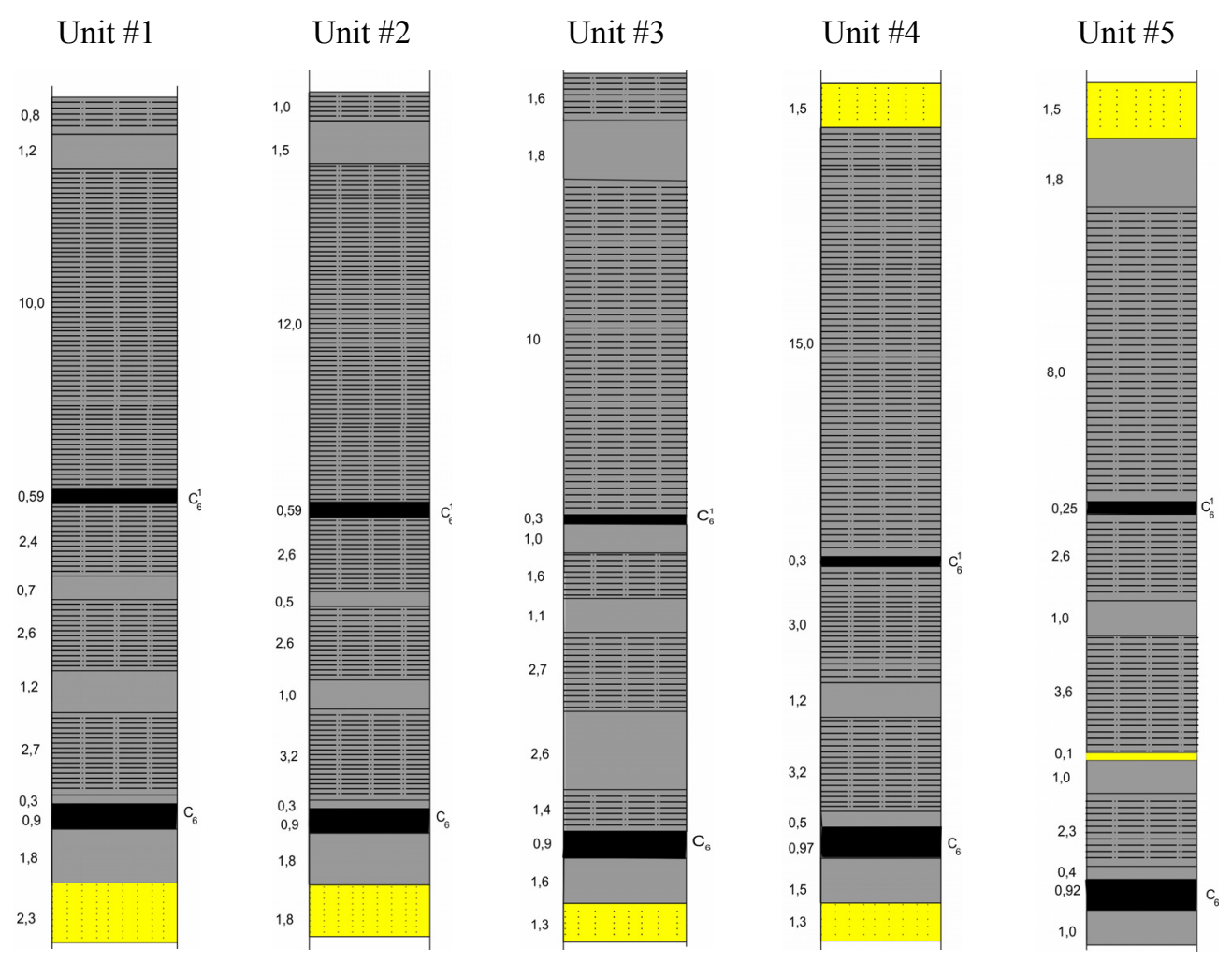

Fig. 1. Structure of main roof on investigated units

Influence of parameter $\Delta_{f}$ on loading character of mechanized support sections is enough visibly (fig. 2). Therefore to reach adequateness of results it is necessary to maximally equalize analyzed groups of sections on parameter $\Delta_{f}$. Inasmuch as system advancing is conducted automatically, we can emphasize three locations of sections towards wall face: 1) maximally advanced $(320-470 \mathrm{~mm}) ; 2)$ in medium position $(621-770 \mathrm{~mm})$; maximally removed in depth of massif $(921-1070 \mathrm{~mm})$ (fig. 2).

As we can see from fig. 2, to exclude influence of factor $\Delta_{f}$ it is necessary to use sections with minimal loading in further research, i.e. sections that maximally advanced to face (fig. 2, blue line).

Let's consider influence of section location along the length of longwall (fig. 2). Inasmuch as stoping face form has arc form it is necessary to check load distribution along the length of longwall.

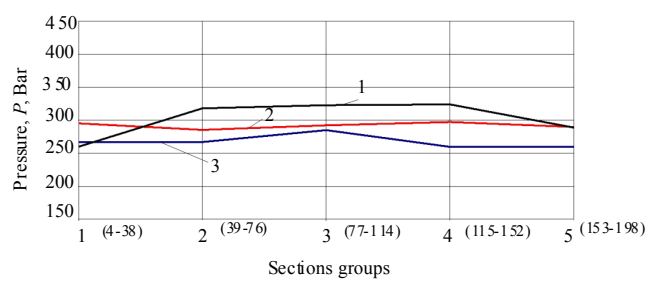

Fig. 2. Pressure in support sections in view of factor along the length of longwall at $V_{f}=9 \mathrm{~m} /$ day: $1-\Delta f=921-1070 \mathrm{~mm} ; 2-\Delta f=621-770 \mathrm{~mm}$; $3-\Delta f=320-470 \mathrm{~mm}$

Central part of longwall has advancing before junctions between extraction mine workings on the average $9-12 \mathrm{~m}$ that is practi- 
cally unessentially for loading on mechanized support at longwall length $200-250 \mathrm{~m}$.

As we can see from fig. 2, coordinate of section location along the length of longwall practically hasn't affected on mechanized support loading:

- as a consequence remain two factors that have influence on character of sections loading - face stopping time $-t_{\text {stop }}$ and advance rate of stoping face - at $V_{f}$;

- surveying of instrumental data were conducted (fig. 1) on units \#1 (2 days) and \#2 (2 days).

Data techniques processing that allowing more authentically analyze results of monitoring were developed.

Essence of this methodology is following:

- surveying of instrumental data on investigated unit conducts within two days;

- longwall is divided into 5 units where conduct averaging of instrumental data of pressure in hydraulic prop;

- with a view to ensuring results authenticity, we choose units with similar structure of main roof and also exclude influence of those factors that wasn't analyzed in this experiment.

Results of conducted research are represented on fig. 3 .

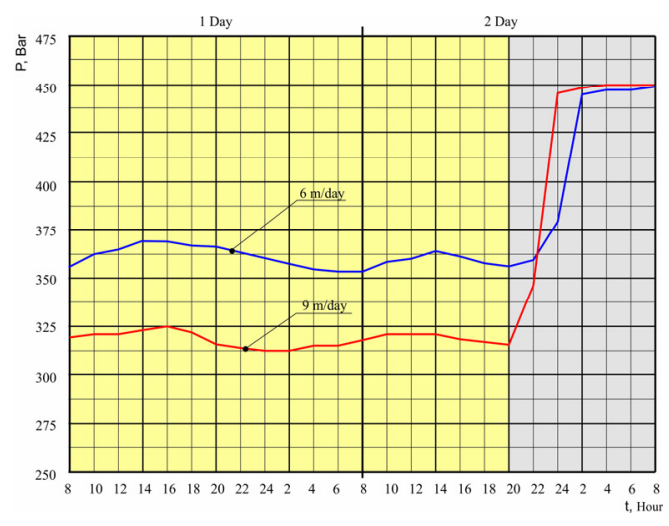

Fig. 3. Pressure variation in support sections of plow system in standard operating procedure (1 day) and during face stopping (2 days) at advance rate $6 \mathrm{~m} /$ day and $9 \mathrm{~m} /$ day: $\square$ - standard operating procedure of face; $\square$-face stopping
In such case were analyzed those units where longwall on first day moved with average rate near $6 \mathrm{~m} /$ day and $9 \mathrm{~m} /$ day, whereat on second day happened face stopping with duration near 12 hours because of organization and technical reasons.

In standard operating procedure of extraction unit mining when longwall moves with stable speed without longtime stopping, loading character is qualitatively similar to both advance rates. It differs only by short time increasing of loading during repair work time in consequence of operational downtime. However, at advance rate $6 \mathrm{~m} /$ day average load in standard operating procedure is equal to 355 Bar $(35.5 \mathrm{MPa})$, but at $9 \mathrm{~m} /$ day is not more than 325 Bar (32.5 MPa). Difference is equal to $10 \%$.

During longtime stopping of extraction unit (to 12 hours) is observed following regularities of loading changing on support sections:

- first stage -4 hours - pressure growth in support sections for longwall that moving with rate 6 and $9 \mathrm{~m} /$ day is significantly differs. In first case pressure grew to $377 \mathrm{Bar}(37.7 \mathrm{MPa})$ and equal to $6.19 \%$ from pressure during standard operating procedure (355 Bar), but in second one is equal to $448 \mathrm{Bar}(44.8 \mathrm{MPa})$ that is $37.84 \%$ from standard (325 Bar);

- second stage -8 hours - pressure rises along the sections to maximum in $450 \mathrm{Bar}$ (45.0 MPa).

Based on abovementioned, different character of support loading is observed and in second case $(9 \mathrm{~m} /$ day) pressure rises significantly harder.

\section{CONCLUSIONS}

Based on realized research we can make following conclusions:

1. For receiving adequate results it is necessary to choose units with similar lithological composition of roof, rocks that have similar strength and deformational characteristics for supplying authentic loading character from the side of overlying massif.

2. For excluding from analysis influence 
of factor $V_{f}$ applies monitoring data only for maximum advanced to face sections.

3 . At advance rate $6 \mathrm{~m} /$ day average loading in standard operational procedure is equal to $355 \mathrm{Bar}(35.5 \mathrm{MPa})$, but at $9 \mathrm{~m} /$ day not more than $325 \mathrm{Bar}(32.5 \mathrm{MPa})$.

4. During longwall stopping on term to 4 hours at at $V_{f}=6 \mathrm{~m}$ /day pressure rose to $377 \mathrm{Bar}(37.7 \mathrm{MPa})$ that is equal to $6.19 \%$ from standard (355 Bar), but at $V_{f}=9 \mathrm{~m} /$ day $448 \mathrm{Bar}(44.8 \mathrm{MPa})$ that is $37.84 \%$ from standard (325 Bar).

\section{PROSPECTS OF FURTHER RESEARCH}

Further research of given problem can be separated on few directions, each of which are very perspective and have great scientific and practical meaning for longwall non-stop operation guarantee:

1. Definition of more rational advance rate (both minimal and maximal).

2. Definition of further character of pressure rise on support after longwall stoppings of different duration with taking into account advance rate and main roof structure.

3. Definition of main roof structure influence on character of support sections loading both during standard operational procedure and during stoppings of different duration.

4. Definition of factor $V_{f}$ influence on distance to wall faces as the main part at multivariant analysis.

\section{REFERENCES}

1. Савостьянов А.В Управление состоянием массива горных пород / А.В. Савостьянов, В.Г. Клочков. - К.: УМК BO, 1992. $-273 \mathrm{C}$.

2. Технология и техника, повышающие производительность труда и качество угля / [И.А. Кияшко, Н.П.Овчинников, В.П. Сердюк, А.Г. Кошка] // Уголь Украины. - 1995. - № 6. -27 с.

3. Савостьянов А.В. Методика определения полостей расслоения в подработанном горном массиве / А.В. Савостьянов, В.И. Сулаев, С.П. Григорьев // Науковий вісник НГУ. - 2004. - № 10. - С. $40-41$.

4. Геомеханика нагружения крепи очистных и подготовительных выработок в слоистом массиве слабых пород: монография / [Бондаренко В.И., Ковалевская И.А., Симанович Г.А., Черватюк В.Г.]. - Д.: ЛізуновПрес. 2012. -233 c.

\section{ABOUT AUTHORS}

Demydov Maksym Serhiyovych - assistant of Underground Mining Department at National Mining University.

Shapovalov Yakiv Andriyovych - Ph.D of Underground Mining Department at National Mining University.

Astafiev Denys Olehovych - Ph.D of Underground Mining Department at National Mining University.

Demchenko Yurii Ivanovych - associate professor of Underground Mining Department at National Mining University. 
